\title{
Detection of Prostate Cancer with Complexed PSA AND COMPleXed/TOTAL PSA RATiO - Is THERE ANy Advantage?
}

\author{
F. Strittmatter ${ }^{1}$, P. Stieber ${ }^{2}$, D. Nagel ${ }^{2}$, C. Füllhase ${ }^{1}$, S. Walther ${ }^{1}$, C. G. Stief ${ }^{1}$, R. Waidelich ${ }^{1}$ \\ 1Department of Urology, Hospital of the University of Munich - Campus Grosshadern, Munich, Germany \\ ${ }^{2}$ Institut of Clinical Chemistry, Hospital of the University of Munich - Campus Grosshadern, Munich, Germany
}

\begin{abstract}
Objective: To evaluate the performance of total PSA (tPSA), the free/total PSA ratio ( $\mathrm{f} / \mathrm{tPSA})$, complexed PSA (cPSA) and the complexed/total PSA ratio (c/tPSA) in prostate cancer detection.

Methods: Frozen sera of 442 patients have been analysed for tPSA, free PSA (fPSA) and cPSA. $131 \mathrm{pa}-$ tients had prostate cancer and 311 patients benign prostatic hyperplasia.

Results: Differences in the distribution of the biomarkers were seen as follows: tPSA, cPSA and c/tPSA were significantly higher in the PC group, and f/tPSA was significantly higher in the $\mathrm{BPH}$ group. In the tPSA-range of $0-4 \mathrm{ng} / \mathrm{ml}$ none of the biomarkers showed a significant difference in the distribution between both groups. In the tPSA-ranges of $0-10 \mathrm{ng} / \mathrm{ml}$, 2-10 $\mathrm{ng} / \mathrm{ml}, 4-10 \mathrm{ng} / \mathrm{ml}$ and $<10 \mathrm{ng} / \mathrm{ml}$, f/tPSA showed the highest specificity at high sensitivtities, followed by c/tPSA, cPSA, and tPSA, respectively. In tPSA-ranges greater than $10 \mathrm{ng} / \mathrm{ml}$, cPSA offered the best discriminatory ability. CPSA compared to tPSA offered better specificity at high sensitivities in all tPSA-ranges.

Conclusion: F/tPSA offers the best ability to distinguish between both groups in lower tPSA-ranges, followed by c/tPSA. CPSA compared to tPSA offers a better ability to discriminate between both groups in all PSA-ranges and could be used as an initial test for PC.
\end{abstract}

Key words: Prostate cancer, tPSA, cPSA, ratio f/tPSA, ratio $\mathrm{c} / \mathrm{tPSA}$, detection of prostate cancer, benign hyperplasia of the prostate

Abbreviations: $\mathrm{PC}=$ prostate cancer, $\mathrm{BPH}=$ benign hyperplasia of the prostate, PSA $=$ prostate specific antigen, $\mathrm{tPSA}=$ total PSA, $\mathrm{cPSA}=$ complexed PSA, $\mathrm{fPSA}=$ free PSA, $\mathrm{f} / \mathrm{tPSA}=$ ratio free to total PSA, $\mathrm{c} / \mathrm{tPSA}=$ ratio complexed PSA to total PSA

\section{INTRODUCTION}

Prostate cancer (PC) is the most diagnosed cancer in men. In the European Union, prostate cancer accounts for approximately $11 \%$ of all cancers and $9 \%$ of all cancers deaths [1]. The diagnosis of PC is based on a combination of digital-rectal examination (DRE), testing of the prostate specific antigen (PSA) and the transrectal ultrasound guided biopsy (TRUS-biopsy). Testing of PSA and the digital-rectal examination are both limited with regard to their low sensitivity and specificity. Consequently, patients are often undergoing histological examination by prostate biopsy because of an elevated PSA or an abnormal DRE without having prostate cancer. A serum PSA measurement of $4 \mathrm{ng} / \mathrm{ml}$ is often still regarded as the threshold above which prostate biopsy is performed. With this cut-off of PSA, sensitivities of $80 \%$ to $91 \%$ and specificities from $28 \%$ to $85 \%$ can be found. Nevertheless there are several studies in the literature which have shown $22 \%$ to $24 \%$ of men with prostate cancer in a PSA value between 2.5 to $4 \mathrm{ng} / \mathrm{ml}$. Approximately $70 \%$ of them have a clinically significant PC $[2,3]$. Clinically significant PCs are mostly cancers which are localised in the prostate and have a potential to be treated curatively.

Due to this limitation, there is a constant or continuous effort to improve the diagnostic tools for the detection of prostate cancer. The most promising approach to improve the specificity of PSA, particularly in the range lower $10 \mathrm{ng} / \mathrm{ml}$, is the measurement of molecular isoforms of PSA. These are the disengaged free PSA (fPSA) and the complexed PSA (cPSA) bound to $\alpha 1$-antichymotrypsin. Several studies have shown an increase in sensitivities and specificities, primarily in the PSA range of lower $10 \mathrm{ng} / \mathrm{ml}$, for the ratio of free to total PSA ( $\mathrm{f} / \mathrm{tPSA}$ ). They affirm that $\mathrm{f} / \mathrm{tPSA}$ can better distinguish between patients with prostate cancer from patients with a benign hyperplasia of the prostate. For cPSA, the data in the actual literature are inconsistent. Some offer an improvement in the early detection of PC and others do not $[4,5]$.

The aim of our study was to evaluate the diagnostic performance of tPSA, cPSA and the associated $\mathrm{f} / \mathrm{tPSA}$ and $\mathrm{c} / \mathrm{tPSA}$ ratios for differentiating between patients with PC and BPH.

\section{Materials, Methods and Statistics}

Patients: Serum samples were obtained from a total of 442 patients in the Department of Urology, Munich, Germany. The study was performed with retrospective sera in accordance with the ethical standards of the Helsinki Declaration 1985. All patients have been divided into two groups. 
Benign byperplasia of the prostate: This group included 311 patients (median age: 66, range: 26-89). The diagnosis was established clinically by digital rectal examination (enlarged, confined and indolent with smooth surface and no indurations) and transrectal ultrasound (enlarged organ without hypoechoic areas suggestive of PC). The histological examination was performed ultrasound guided prostate biopsy.

Prostate cancer group: A total of 131 patients have been enrolled (median age: 66, range 47-92). The histopathologically diagnosis of prostate cancer has been established by examination of the prostate after biopsy or radical prostatectomy. The cancer stage was assigned according the TNM-System. The histological grade was classified as grades 1,2 and 3 and by the Gleason-score.

Sample collection: Blood samples were taken before any diagnostic or therapeutic measures involving the prostate. The blood samples were collected in evacuated tubes (S-Monovette $10 \mathrm{~m}$, Sarstedt GmbH, Sarstedt, Germany) and centrifuged at $1600 \mathrm{~g}$ for at least 15 minutes at 4C. Samples were stored at $-80 \mathrm{C}$ within 3 hours after collection and not thawed before analysis. All samples have been analyzed at the Institute of Clinical Chemistry, Hospital of the University of $\mathrm{Mu}-$ nich - Campus Grosshadern, Munich, Germany.

Assays: Identification of tPSA and fPSA were performed with the Roche Elecsys PSA immunoassay (ECLIA, Roche Diagnostics GmbH, Mannheim, Germany) on the fully automated Elecsys analyser 1010 according to the instruction of the manufactures. CPSA was determined by the immunoassay for the Bayer ADVIA Centaur. Also in the measurement of cPSA the instruction of the manufactures were fully followed. These measurements were performed in the year 2006 .

Statistical Analysis: Data were analyzed using statistical SAS software (SAS V9.1, SAS Institute Inc., Cary, NC). The Wilcoxon rank-sum test and the correlation coefficients according to Spearman (rs) were calculated. The diagnostic validity was evaluated by the receiver operating characteristic (ROC) curves and the area under the curve (AUC). P values $\leq 0.05$ were considered to reflect statistical significance.

\section{RESULTS}

Distribution of the different PS A forms and their ratios with range and median: TPSA was distributed in the BPH group with a range of 0.1-39.1 ng/ml (median of $3.2 \mathrm{ng} / \mathrm{ml}$ ) and in the PC group with a range of $0.1-1347 \mathrm{ng} / \mathrm{ml}$ (median of $13.7 \mathrm{ng} / \mathrm{ml}$ ), respectively. The distribution of the ratio $\mathrm{f} / \mathrm{tPSA}$ in the group with $\mathrm{BPH}$ was $0.02-1.0$ (median 18\%) and 0.03-1.0 (10\%) respectively. The dispersion of cPSA in the $\mathrm{BPH}$ group was $0.01-32 \mathrm{ng} / \mathrm{ml}$ (median $1.7 \mathrm{ng} / \mathrm{ml}$ ) and $0.01-989 \mathrm{ng} / \mathrm{ml}$ (median $9.02 \mathrm{ng} / \mathrm{ml}$ ) in the group with PC. For the distribution of $\mathrm{c} / \mathrm{tPSA}$ a range of 0.07-0.91 (median 0.057) was found for the BPH group and a range of $0.02-0.89$ (median 0.66) for the PC group, respectively.
The concentrations of tPSA, its ratio $\mathrm{f} / \mathrm{tPSA}$, cPSA and the ratio $\mathrm{c} / \mathrm{tPSA}$ were significantly different between both study groups. TPSA, cPSA and c/tPSA were significantly higher in the PC group and, as expected, $\mathrm{f} / \mathrm{tPSA}$ was significantly higher in the BPH group.

Relationship of tPSA, f/tPSA, cPS A and c/tPSA amongst each other and to tumor staging and grading: CPSA values ( $\mathrm{rs}=0.983$ and $\mathrm{rs}=0.991$ ) for $\mathrm{BPH}$ and PC patients were more closely related to tPSA values than to fPSA values $(\mathrm{rs}=0.854$ and $\mathrm{rs}=0,841)$. There was no direct relationship between tPSA, cPSA, $\mathrm{f} / \mathrm{tPSA}$ and the ratio c/tPSA to tumor stage. In consideration of the relationship between the different PSA forms and their ratios as well as the tumour grading, the ratio $\mathrm{f} / \mathrm{tPSA}$ had the best power in differentiation between the BPH-group and low grade tumors, followed by cPSA, tPSA and c/tPSA, respectively.

In regards to the high grade tumors, cPSA had the best power to discriminate between both groups, followed by tPSA, f/tPSA, and c/tPSA, respectively.

Analysis in sum and in respect to different tPS Aranges: In the present study $\mathrm{ROC}$ analyses have been made in the total range and in taking different tPSAranges into account. The Receiver Operating Characteristic Curves (ROC) and their area under the curves (AUC) are shown in Figure 1 for the whole patient collective. The areas under the ROC curves were 0.786 for tPSA, 0.799 for cPSA, 0.759 for $\mathrm{f} / \mathrm{tPSA}$ and 0.698 for $\mathrm{c} / \mathrm{tPSA}$. Figures 2 to 6 show the different areas under the ROC curves in respect to different tPSA ranges. Figure 2 for the range $0-4 \mathrm{ng} / \mathrm{ml}$, Figure 3 for the range $2-10 \mathrm{ng} / \mathrm{ml}$, Figure 4 for $4-10 \mathrm{ng} / \mathrm{ml} \mathrm{tPSA}$ and Figure 5 shows the range of tPSA 0 to $10 \mathrm{ng} / \mathrm{ml}$. In Figure 6, all patients with a tPSA value of greater than $10 \mathrm{ng} / \mathrm{ml}$ are considered. As illustrated in Figure 2 , there are no significant differences in the distribution of all parameters between both study groups $(\mathrm{p}>$ $0.05)$. In the tPSA range of $2-10 \mathrm{ng} / \mathrm{ml}, 4-10 \mathrm{ng} / \mathrm{ml}$ and $0-10 \mathrm{ng} / \mathrm{ml}$ significant distribution between $\mathrm{pa}-$ tients with $\mathrm{BPH}$ and PC could be found except for tPSA in the range of $4-10 \mathrm{ng} / \mathrm{ml} \mathrm{tPSA}$. Considering the range of tPSA greater than $10 \mathrm{ng} / \mathrm{ml}$, all parameters have been significantly distributed in respect to both study groups (Fig. 6).

\section{DisCusSION}

The identification of tPSA, the digital-rectal examination and the ultrasonography of the prostate are still the recommended analytic methods to decide whether or not a patient should undergo a biopsy of the prostate for detection prostate cancer [6]. All examinations are limited because of their deficient sensitivity and specificity. To improve the early detection of PC, various PSA forms seem to be an established way for the early detection of PC. It is of great interest to the urologist to avoid unnecessary biopsies and anticipate the distress of treated patients [7,8]. Serum PSA has an acceptable sensitivity but also has a low specificity the reason for this being an increased level of PSA in the serum of patients with benign prostatic disease [9]. Other concepts to enhance the diagnostic validity of 

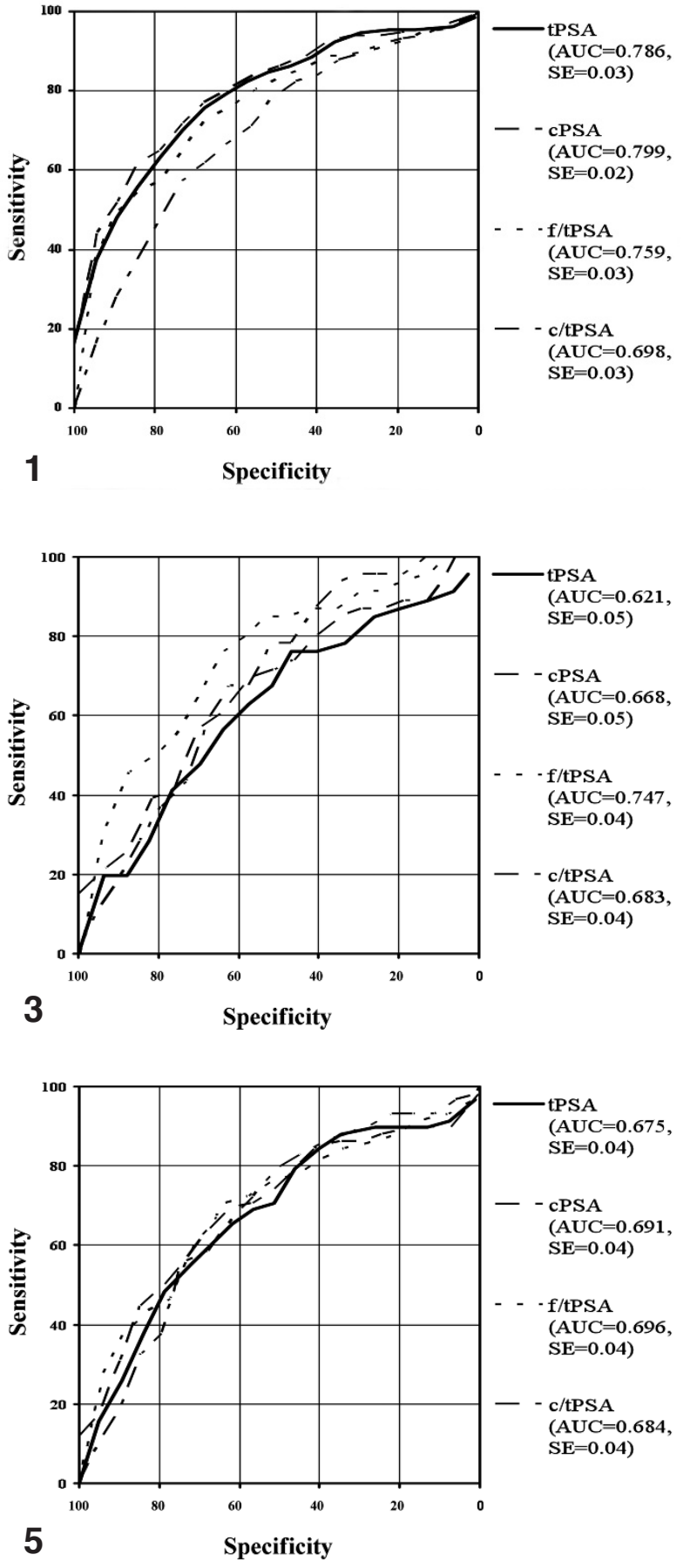
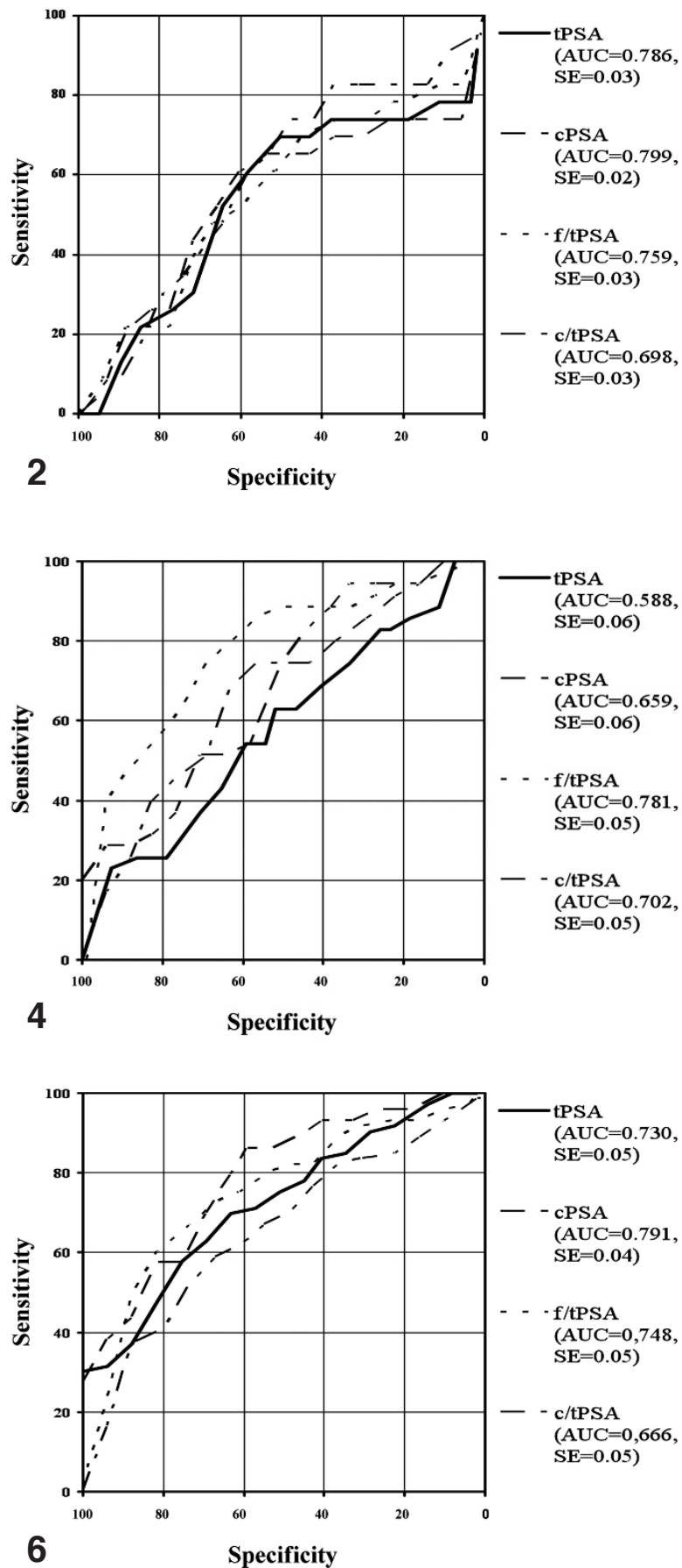

Figs. 1-6. ROC-Analysis of different PSA-ranges: Figure 1 includes the whole collective, Figure 2: tPSA-ranges 0-3.9 ng/ml, Figure 3: 2-10 $\mathrm{ng} / \mathrm{ml}$ tPSA, Figure 4 includes tPSA-range 4-10 ng/ml, Figure 5: 0-10 ng/ml and Figure 6: $>10 \mathrm{ng} / \mathrm{ml} \mathrm{tPSA}$.

PSA have been suggested. These include age-related tPSA references ranges, and the velocity and density of PSA, particularly in a tPSA overlapping range [10].

$\operatorname{TPS} A, c P S A, f / t P S A$ and $c / t P S A$ in comparison to the overall study group: Using a cut-off value of 4 $\mathrm{ng} / \mathrm{ml}$ tPSA, our data shows similar sensitivities and specificities of tPSA in comparison to other studies. We found a sensitivity of $82 \%$ and a specificity of $58 \%$. The positive predictive value was $45 \%$ and the negative predictive value was $89 \%$. Tanguay et al. reported from 535 patients , 204 patients had histologi- cally proven prostate cancer and the remaining $311 \mathrm{pa-}$ tients had benign prostate hyperplasia. At a cut-off of $4 \mathrm{ng} / \mathrm{ml}$, the sensitivity was $87 \%$ with a specificity of $27 \%$ [11]. Other studies with a cut-off of $4 \mathrm{ng} / \mathrm{ml}$ had sensitivtities from $80-91 \%$ and specificities from $28-85 \%$ [12-14]. A possible reason for the wide range of specificity could be the use of different assays [15].

Compared to Tanguay et al., the ratio $\mathrm{f} / \mathrm{tPSA}$ showed no benefit in discriminating between patients with prostate cancer and patients with a benign prostatic hyperplasia [11]. Sensitivity was $82 \%$, specificity $55 \%$, the positive predictive value was $43 \%$ and the 
negative predictive value was $87 \%$. These data agree with other published data [16]. It has been shown in numerous studies that the ratio $\mathrm{f} / \mathrm{tPSA}$ in addition to tPSA has the best ability to discriminate between patients with PC and without PC especially in ranges lower than $10 \mathrm{ng} / \mathrm{ml} \mathrm{tPSA}[17,18]$. These findings can be outlined by our data.

In contrasting tPSA to the $\alpha 1$-antichymotrypsin bound cPSA showed at a sensitivity of $82 \%$, a specificity of $60 \%$. The positive predictive value was $46 \%$ and the negative predictive value was $89 \%$. Unnecessary biopsies of 5 patients with BPH could have been avoided using cPSA instead of tPSA. The data for using cPSA instead of tPSA are still controversial. Stenman et al. were the first investigators to note that cPSA is the major form of PSA with PC [7]. Brawer et al. showed in a patient population of 300 patients that the AUC with 0.722 of cPSA was higher than the AUC with 0.688 of tPSA. Considering a sensitivity of $95 \%$, the specificity was $26.7 \%$ and $4.9 \%$ higher than the specificity of tPSA [12]. Our data showed an AUC for cPSA of 0.798 and an AUC for tPSA of 0.785 . Another study by Brawer showed a significantly higher specificity for cPSA in comparison to tPSA in a study population of 657 patients altogether [13]. Other studies could not find a benefit for use of cPSA instead of tPSA in the detection of prostate cancer. Miller at al. published the same discriminating potency for cPSA than for tPSA [19]. Okihara et al. found no advantage in the discrimination between patients with PC and patients with benign disease of the prostate in important clinical sensitivity levels [20].

We also examined the ratio of $\mathrm{c} / \mathrm{tPSA}$ in our study. In comparison to tPSA, cPSA and the ratio $\mathrm{f} / \mathrm{tPSA}$, sensitivity of $\mathrm{c} / \mathrm{tPSA}$ is lower and offers no advantage in the discrimination of both study groups in respect to the whole study population. These data are in contrast to the published data from Jung et al. [21]. Jung et al. found the same diagnostic power for the ratio $\mathrm{c} / \mathrm{tPSA}$ as for the ratio of $\mathrm{f} / \mathrm{tPSA}$. Okihara et al. had shown no increase in the discrimination power between both study groups in comparison to the ratio $\mathrm{f} / \mathrm{tPSA}$. But the ratio of $\mathrm{c} / \mathrm{tPSA}$ did show better sensitivities and specificities than tPSA and cPSA [20].

$\operatorname{TPS} A, c P S A, f / t P S A$ and $c / t P S A$ in comparison to different tPS $A$ ranges: It is well known that the discrimination between patients with and without prostate cancer in tPSA ranges of $<10 \mathrm{ng} / \mathrm{ml}$ is often difficult and this is part of the major problem in deciding if a biopsy of the prostate is necessary or not. In the tPSA range of $<4.0 \mathrm{ng} / \mathrm{ml}$ our data shows no discrimination power between study groups. This has already been published by Lein et al. who compared two study groups with and without prostate cancer in a PSA-range of lower than $4.0 \mathrm{ng} / \mathrm{ml}$. Lein et al. also found no discrimination power of all biomarkers in their study population [22]. In contrast, Okihara et al. did find a benefit of cPSA against the ratio $\mathrm{f} / \mathrm{tPSA}$ in the tPSA-range of $<4.0 \mathrm{ng} / \mathrm{ml}$ [23]. Our data do not agree with theirs. Interestingly, we found in the tPSArange lower than $4.0 \mathrm{ng} / \mathrm{ml} 4$ patients with a prostate cancer in the 44 -stadium and 3 patients in t3-stadium. 6 patients had a Gleason score $\geq 7$. Similar findings were published by Thompson et al. 2004. They showed the presence of inappropriate tumors in PSAranges lower $4 \mathrm{ng} / \mathrm{ml}$ [24].

To consider the tPSA-range of $4-10 \mathrm{ng} / \mathrm{ml}$, our data show the best discrimination power by the ratio of $\mathrm{f} / \mathrm{tPSA}$. In the range of $4-10 \mathrm{ng} / \mathrm{ml}$ we found 35 patients with a prostate cancer and 81 patients with $\mathrm{BPH}$ in our study. For example, \at a sensitivity of $85 \%$, the ratio of $\mathrm{f} / \mathrm{tPSA}$ was $58 \%$, followed by the ratio c/tPSA with a specificity of $40 \%$. The specificity of cPSA in respect to a sensitivity of $85 \%$ was $28 \%$. The specificity of tPSA was $19 \%$. Interestingly, tPSA was not able to discriminate between both study groups (AUC $=0.588, \mathrm{p}>0.05)$. These findings are in accordance with published data from Catalona et al. Catalona et al. also found the best discrimination power to be in the range of $4-10 \mathrm{ng} / \mathrm{ml}$ for $\mathrm{f} / \mathrm{tPSA}$ (1998). Brawer published the advantage of $\mathrm{f} / \mathrm{tPSA}$ against cPSA in total and in the range of $4-10 \mathrm{ng} / \mathrm{ml}$. The diagnostic sensitivity was significantly better in both PSA-ranges [13]. The benefit of the use of $f / t P S A$ is obvious. However there exist some limitations which should be considered. The use of different assays for the identification of tPSA and fPSA leads to different cut-off-values [25]. The age of the patients must be taken into consideration [26]. FPSA is a very unstable marker. For example the concentration of fPSA decreases by frozen storage [27]. This fact must be considered in our data as well.

Taking the ranges of $2-10 \mathrm{ng} / \mathrm{ml}$ and $<10 \mathrm{ng} / \mathrm{ml}$ tPSA into account for the best discrimination between both study groups was achieved by the ratio $\mathrm{f} / \mathrm{tPSA}$, followed by the ratio c/tPSA, cPSA and than tPSA. In the range of $2-10 \mathrm{ng} / \mathrm{ml}$ our data are analogous to the range of $4-10 \mathrm{ng} / \mathrm{ml}$, a diagnostic benefit for cPSA compared to tPSA. These data agree with other published data [28]. In published data from Jung et al. the ratio $\mathrm{c} / \mathrm{tPSA}$ had a better discrimination power than cPSA and tPSA in lower tPSA-ranges. Our data confirm this findings [21].

In tPSA ranges of $>10 \mathrm{ng} / \mathrm{ml}$ cPSA offered the best discriminatory power between both study groups, followed by tPSA, the ratios $\mathrm{f} / \mathrm{tPSA}$ and the ratio c/tPSA, respectively. The diagnostic power of cPSA in comparison to tPSA was also found by Mitchell et al. in these tPSA-ranges [29].

\section{CONCLUSION}

In conclusion, our data show the limitation of the different biomarkers and their ratios in total and in different PSA-ranges in respect to high sensitivities. In the ranges of $2-10 \mathrm{ng} / \mathrm{ml}, 4-10 \mathrm{ng} / \mathrm{ml}$ and $<10 \mathrm{ng} / \mathrm{ml}$ the ratio of $\mathrm{f} / \mathrm{tPSA}$ provides the best results in discrimination between both study groups. Without doubt the ratio $\mathrm{f} / \mathrm{tPSA}$ can be an additional tool for the decision of whether or not a biopsy of the prostate should be performed in lower tPSA-ranges. The instability of the free PSA and the particular claim in the determination must be mentioned. The ratio of $\mathrm{c} / \mathrm{tPSA}$ offered better specificities in lower tPSA-ranges than tPSA and cPSA, but its limited practicality as a result of the need for two different assays. The $\alpha 1$-antichymotrypsin bound cPSA was superior to 
tPSA in all tPSA-ranges and could be used as a single test in the detection of prostate cancer. Because of the aforementioned limitations of the different biomarkers, further studies are necessary to find improved markers for the detection of prostate cancer to reduce the number of patients who undergo a prostate biopsy without having prostate cancer.

Acknowledgment: We thank K. Hofmann for excellent technical assistance.

\section{REFERENCES}

1 Heidenreich A, Aus G, Bolla M, Joniau S, Matveev VB, Schmid HP, Zattoni F: Eau guidelines on prostate cancer. Eur Urol 2008;53:68-80.

2 Catalona WJ, Smith DS, Ornstein DK: Prostate cancer detection in men with serum psa concentrations of 2.6 to $4.0 \mathrm{ng} / \mathrm{ml}$ and benign prostate examination. Enhancement of specificity with free psa measurements. Jama 1997;277:1452-1455.

3 Babaian RJ, Johnston DA, Naccarato W, Ayala A, Bhadkamkar VA, Fritsche HH, Jr.: The incidence of prostate cancer in a screening population with a serum prostate specific antigen between 2.5 and $4.0 \mathrm{ng} / \mathrm{ml}$ : Relation to biopsy strategy. J Urol 2001;165:757-760.

4 Parsons JK, Brawer MK, Cheli CD, Partin AW, Djavan R: Complexed prostate specific antigen (psa) reduces unnecessary prostate biopsies in the $2.6-4.0 \mathrm{ng} / \mathrm{ml}$ range of total psa. BJU Int 2004;94:47-50.

5 Parsons JK, Partin AW: Applying complexed prostatespecific antigen to clinical practice. Urology 2004;63:815818.

6 Heidenreich A, Aus G, Bolla M, Joniau S, Matveev VB, Schmid HP, Zattoni F: [eau guidelines on prostate cancer]. Actas Urol Esp 2009;33:113-126.

7 Stenman UH, Leinonen J, Alfthan H, Rannikko S, Tuhkanen $\mathrm{K}$, Alfthan O: A complex between prostate-specific antigen and alpha 1-antichymotrypsin is the major form of prostate-specific antigen in serum of patients with prostatic cancer: Assay of the complex improves clinical sensitivity for cancer. Cancer Res 1991;51:222-226.

8 Woodrum DL, Brawer MK, Partin AW, Catalona WJ, Southwick PC: Interpretation of free prostate specific antigen clinical research studies for the detection of prostate cancer. J Urol 1998;159:5-12.

9 Catalona WJ: Screening for prostate cancer. Lancet 1994;343:1437.

10 Ukimura O, Durrani O, Babaian RJ: Role of psa and its indices in determining the need for repeat prostate biopsies. Urology 1997;50:66-72.

11 Tanguay S, Begin LR, Elhilali MM, Behlouli H, Karakiewicz PI, Aprikian AG: Comparative evaluation of total psa, free/total psa, and complexed psa in prostate cancer detection. Urology 2002;59:261-265.

12 Brawer MK, Meyer GE, Letran JL, Bankson DD, Morris DL, Yeung KK, Allard WJ: Measurement of complexed psa improves specificity for early detection of prostate cancer. Urology 1998;52:372-378.

13 Brawer MK, Cheli CD, Neaman IE, Goldblatt J, Smith C, Schwartz MK, Bruzek DJ, Morris DL, Sokoll LJ, Chan DW, Yeung KK, Partin AW, Allard WJ: Complexed prostate specific antigen provides significant enhancement of specificity compared with total prostate specific antigen for detecting prostate cancer. J Urol 2000;163: 1476-1480.

14 Chakrabarti S, Raha K, Bhunia CL, Bhattachary DK: The usefulness of prostate specific antigen density as a screening method for prostatic carcinoma. J Indian Med Assoc 2001;99:627-628, 630 .
15 Reiter W, Stieber P, Schmeller N, Nagel D, Schambeck C, Fateh-Moghadam A: Is free prostate-specific antigen helpful in the differential diagnosis of benign hyperplasia and cancer of the prostate? Tumour Biol 1997;18:80-87.

16 Trinkler FB, Schmid DM, Hauri D, Pei P, Maly FE, Sulser T: Free/total prostate-specific antigen ratio can prevent unnecessary prostate biopsies. Urology 1998;52: 479-486.

17 Lein M, Stephan C, Jung K, Schnorr D, Loening S: Relation of free psa/total psa in serum for differentiating between patients with prostatic cancer and benign hyperplasia of the prostate: Which cutoff should be used? Cancer Invest 1998;16:45-49.

18 Espana F, Royo M, Martinez M, Enguidanos MJ, Vera CD, Estelles A, Aznar J, Jimenez-Cruz JF, Heeb MJ: Free and complexed prostate specific antigen in the differentiation of benign prostatic hyperplasia and prostate cancer: Studies in serum and plasma samples. J Urol 1998;160: 2081-2088.

19 Miller MC, O'Dowd GJ, Partin AW, Veltri RW: Contemporary use of complexed psa and calculated percent free psa for early detection of prostate cancer: Impact of changing disease demographics. Urology 2001;57:11051111.

20 Okihara K, Cheli CD, Partin AW, Fritche HA, Chan DW, Sokoll LJ, Brawer MK, Schwartz MK, Vessella RL, Loughlin KR, Johnston DA, Babaian RJ: Comparative analysis of complexed prostate specific antigen, free prostate specific antigen and their ratio in detecting prostate cancer. J Urol 2002;167:2017-2023; discussion 2023-2014.

21 Jung K, Elgeti U, Lein M, Brux B, Sinha P, Rudolph B, Hauptmann S, Schnorr D, Loening SA: Ratio of free or complexed prostate-specific antigen (psa) to total psa: Which ratio improves differentiation between benign prostatic hyperplasia and prostate cancer? Clin Chem 2000;46:55-62.

22 Lein M, Kwiatkowski M, Semjonow A, Luboldt HJ, Hammerer P, Stephan C, Klevecka V, Taymoorian K, Schnorr D, Recker F, Loening SA, Jung K: A multicenter clinical trial on the use of complexed prostate specific antigen in low prostate specific antigen concentrations. J Urol 2003;170:1175-1179.

23 Okihara K, Ukimura O, Nakamura T, Mizutani Y, Kawauchi A, Naya Y, Uchida M, Ogiwara T, Miki T: Can complexed prostate specific antigen enhance prostate cancer detection in japanese men? Eur Urol 2004;46:5764.

24 Thompson IM, Pauler DK, Goodman PJ, Tangen CM, Lucia MS, Parnes HL, Minasian LM, Ford LG, Lippman SM, Crawford ED, Crowley JJ, Coltman CA, Jr.: Prevalence of prostate cancer among men with a prostate-specific antigen level $<$ or $=4.0 \mathrm{ng}$ per milliliter. N Engl J Med 2004;350:2239-2246.

25 Junker R, Brandt B, Zechel C, Assmann G: Comparison of prostate-specific antigen (psa) measured by four combinations of free psa and total psa assays. Clin Chem 1997;43:1588-1594.

26 Veltri RW, Miller MC, O'Dowd G J, Partin AW: Impact of age on total and complexed prostate-specific antigen cutoffs in a contemporary referral series of men with prostate cancer. Urology 2002;60:47-52.

27 Sokoll LJ, Bruzek DJ, Dua R, Dunn W, Mohr P, Wallerson G, Eisenberger M, Partin AW, Chan DW: Short-term stability of the molecular forms of prostate-specific antigen and effect on percent complexed prostate-specific antigen and percent free prostate-specific antigen. Urology 2002;60:24-30.

28 Roddam AW, Duffy MJ, Hamdy FC, Ward AM, Patnick J, Price CP, Rimmer J, Sturgeon C, White P, Allen NE: Use of prostate-specific antigen (psa) isoforms for the de- 
tection of prostate cancer in men with a psa level of 2-10 $\mathrm{ng} / \mathrm{ml}$ : Systematic review and meta-analysis. Eur Urol 2005;48:386-399; discussion 398-389.

29 Mitchell ID, Croal BL, Dickie A, Cohen NP, Ross I: A prospective study to evaluate the role of complexed prostate specific antigen and free/total prostate specific antigen ratio for the diagnosis of prostate cancer. J Urol 2001;165:1549-1553.
Received: December 24, 2010 / Accepted: June 3, 2011

Address for correspondence:

Strittmatter Frank, MD

Department of Urology

Ludwig-Maximilians University Hospital

Marchioninistr. 15, 81377 Munich

Germany

Phone: 0049-897095-4868

Fax: 0049-890795-4864

E-mail: Frank.Strittmatter@med.uni-muenchen.de 